\title{
A Strong Brand as a Determinant of Purchase the Case of Sectors, where Advertising in Mass Media Is Banned - on the Example of the Polish Spirits Sector
}

\section{Introduction}

In order to achieve success a company must continually search for development opportunities, respond to change with new or improved products, technologies, and marketing activities to achieve a competitive advantage over other participants on the market [3, 170].

Marketing departments compete to find innovative products as well as interesting means and channels of communication to gain and retain clients. The clients' contentment and satisfaction lead to repeat purchase and even recommendations, which in turn is an affirmation of the company's right of existence. Regular purchase loyalty contributes to an increase in market share, while positive attitudes accompanying loyalty allow companies to raise prices [2, 82]. Eventually all the above result in the company's profit.

A powerful tool combining rationally evaluated functional values based on results and facts with emotional values which are subject to affective evaluation is a strong brand $[5,20]$. A brand gives identity to a product defined in the last century by $\mathrm{Ph}$. Kotler as anything offered to potential buyers to satisfy their needs or desires. A brand also distinguishes the product from its competitors. A brand helps avoid using prices as an instrument of competition, this usually means a decrease in company sales if its competitors offer a similar price. A company with strong brands ensures itself a better competing position, higher profit margins [7, 25-26], loyal customers [10, 45], as well as a larger support from sales intermediaries [10, 49].

\footnotetext{
* Nicolaus Copernicus University, Faculty of Economic Sciences and Management, The Department of Enterprise Management.

** University of Promotion, Warsaw
} 
A brand is a constant element identifying the producer with the product $[8$, 65]. As it is a complex entity, it comprises a combination of functional and emotional values desired and sought for by the customer [14, 340]. It is a composition of numerous elements containing intensified messages which aim to distinguish one commodity or product from all other competing products [16, 87].

The authors' thesis is that a strong brand is the key determinant of market success in the Polish spirits sector. What's interesting is the fact that advertising plays a major role in the building and promotion of brands, while advertising in mass media is completely banned in the spirits sector. The main law banning advertising in this sector is the Act on Alcohol Abuse and Alcoholism Prevention of 26 October $1982^{1}$. Considering the above, communication with customers poses a challenge and alcohol producers have a difficult task of attracting customers to their products, especially to the new ones.

The main beverage in the spirits category is plain vodka, where the contents of each bottle can be brought down to grain alcohol and water. Despite the differences in recipes and production technologies, customers may be of the opinion that these products are in fact one and the same and only differ slightly in taste. In this situation the producer has to reach the potential customers informing them about the quality of the offer and persuade the customers to consider that particular product as unique and make them buy it $[15,182-185]$.

Advertising restrictions impede communication with the customer on a large scale. Budgets are shifted from ATL class media (Above-The-Line; media such as television, radio, press, cinema, outdoor, internet) to selected promotional BTL forms (Below-The-Line; forms such as sales promotion, merchandising etc). Presenting a new product and building brand awareness requires the use of mass media tools and that is why limited use of advertising reduces the number of new brands being launched on the market. Difficulties in creating new strong brands forces alcohol producers to focus on the strength and value of the brands, or on the already existing brands which, from the customer's point of view act as a guarantee of quality of the product and of the production process. Thus the second thesis which logically complements the presented theses model is that, despite the legal restrictions in advertising and promotion it is possible to act in support of the strength of spirits brands. A strong brand shall be understood as a brand with a relatively high brand awareness [11,380], appreciated by buyers $[3,7]$, having a strong position on the market [8, 67].

\section{A background of marketing activities in the spirits sector}

In Poland in the 80's there was no clear distinction between vodka brands. Each Polmos ${ }^{2}$ could produce all the brands existing on the market. Therefore the 
brand of a product was not connected with the producer. It was more connected with a particular recipe, carrying information about the kind of vodka produced under a label. It did not guarantee quality which differed depending on the producer. This resulted in the brands being neglected and underinvested. None of the producers saw any point in investing in products which were not owned by anybody. That is why the only existing brands were the widely available ones which were produced everywhere, like Żytnia, Stołowa, Lajkonik. There were no marketing or promotional activities, nobody took care of distribution, positioning or invested in vodka brands. Shops lacked products; everything would sell so there were absolutely no competition strategies.

The economical transformation that took place in Poland after 1989 gradually changed the market from an imbalance defined as pull, where demand was higher than supply, to a push type imbalance in which producers have to fight to gain clients. Following the division of the market and rights to the trademarks and respective alcohol brands producers started to compete in building their products' brands, especially with emerging foreign brands which were then supported by intensive advertising campaigns. Due to an increased number of covert or indirect advertising of alcoholic beverages the Act on Alcohol Abuse and Alcoholism Prevention was amended in 2001. Advertisement of alcoholic beverages was redefined and a differentiation was made between an advertisement and information used for commercial purposes. The amendment of the Act of 27 April 2001 states that advertising and the promotion of products and services is forbidden if the name, trademark, graphic shape or Some brands disappeared from the market, while others with adequate care and investment of their new owners have survived until today and have taken over much of the market share, like: Luksusowa, Wyborowa, Krakus. Initially until 2001 (in spite of the Act on Alcohol Abuse and Alcoholism Prevention of 26 October 1982) it was possible to use various forms of marketing communication. Exploiting loopholes in the law alcohol was promoted in media such as the TV, radio, the press and billboards.

That moment was exploited by the Bols Vodka producer. The company presented an advertising spot full of sport, pleasure and fun. Blue water in the background, happy young people having fun on the Bols boat (with the Bols logo on its sails). In order to go round the rules Bols used an allusion in its advertising campaign. The word 'vodka' did not appear even once, but the phrase 'the Bols boat' did. The trick is that in Polish the two words rhyme and sound similar (wódka- łódka). This in fact suggests a certain interpretation to the viewer. The advertising spot described above is a perfect example of an indirect advertisement of an alcoholic beverage achieved through the use of an ambiguous phrase and a play on words which both suggest unambiguous associations. The rise in sales in the following years was substantial and sales remained high even after the ban on such advertising was introduced [6, 4-5]. 
Bearing in mind the changes taking place on the market and the introduction of legal restrictions it is worth having a closer look at an analysis of brand popularity based on consumer declarations in the years 1998, when marketing activities were permitted (Figure 1) and 2008 when the complete ban on advertising in the press was in full force (Figure 2).

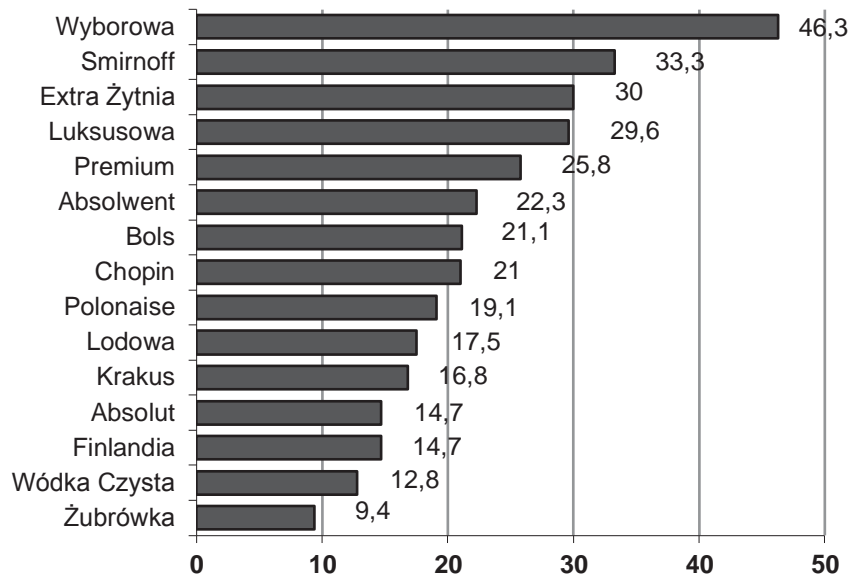

Figure 1. Spontaneous awareness of vodka brands in 1998

Source: SMG/KRC, 1998

In 1998, as has been mentioned before, the main vodka brands were produced by different companies owned by the State as part of Polmos. There were also some foreign brands present on the market at that time. The top vodkas ranked according to popularity are: Wyborowa, Smirnoff, Extra Żytnia, Luksusowa, Premium, Absolwent, Bols, Chopin, Polonaise, Lodowa. In later years there were some significant changes in ownership in the spirits sector. Brands were divided amongst the particular Polmos producers and due to the emerging competition the new sole owners began to pay more attention to their products. The situation in 2010 is shown in Figure 2.

Analyzing the situation in the vodka sector ten years later it may be noticed that some brands, such as Extra Żytnia, Premium, Lodowa, Wódka Czysta have disappeared. Brands remaining at the top of the current awareness and popularity rankings belong to large concerns, the biggest producers in the sector conducting extensive marketing activities and having enormous promotion budgets. The charts presented above also show that consumers have good vodka brand awareness. When questioned they were able to pin point their favorites. It is also clear that 
consumer preferences and their brand awareness have changed over the years. Some brands are gaining popularity while others are losing it. The most popular brands with consumers are at the same time the best selling ones. Changes in the top ranking places are probably caused by creativity in marketing communication on the one hand, and the ability to take advantage of loopholes in the law and promote a brand on the other hand.

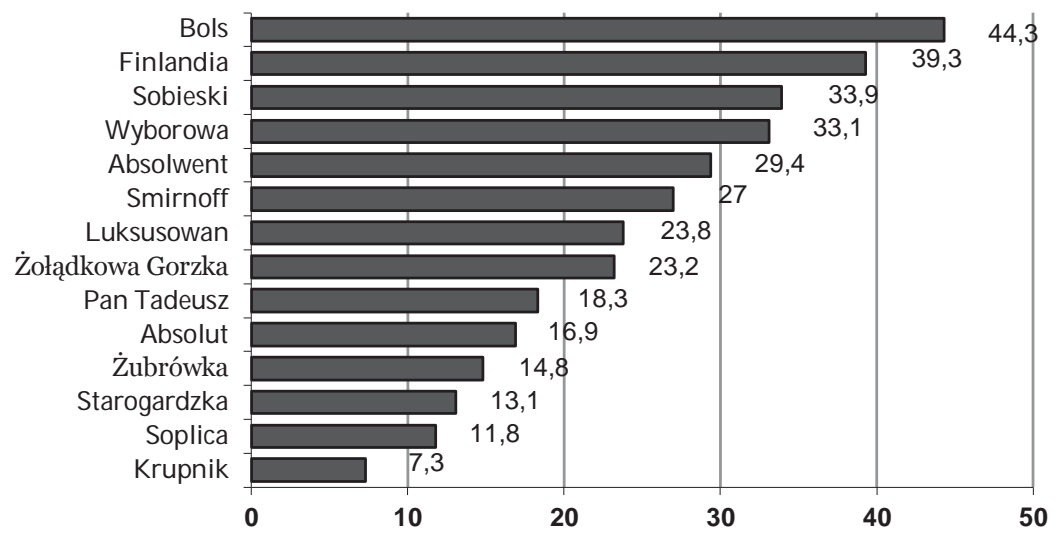

Figure 2. Spontaneous awareness of vodka brands in 2010

Source: SMG/KRC, 2010

\section{Methodology}

The authors' thesis is that a strong brand is the key determinant of market success in the spirits sector and that building strong product brands is possible even in sectors in which mass media advertising is prohibited or for some reason cannot be used. The authors decided to find out what the factors affecting a client's choice are on the spirits market. To discover whether, in spite of legal restrictions the producers are trying to build and create strong brands and how these actions influence clients' decisions and perception of product brands. In conclusion the authors propose a conceptual model for building a strong brand through exploiting the key determining factors in purchasing where advertising is banned.

The paper presents results of two complementary studies. The first study was carried out by means of personal interviews on a trial group of 1501 individual 
respondents in 2007 in Poland. The second study was carried out using personal or Internet questionnaires on a trial group of 16 companies producing or importing spirits. The companies offer the best known and the most significant alcohol brands having $95.95 \%$ of the market share.

The analyses of the results made it possible to determine that a strong brand is not only the key asset in the spirits sector (in a situation where advertising is banned), but is also the determining factor in the clients' purchasing decision.

\section{Key decision elements in vodka purchase}

The process of purchasing vodka is similar to the purchase of other consumer goods the only problem being an impeded communication between the brand owner and the consumer. Figure 3 shows elements which decide in the process of selecting a brand by the consumer.

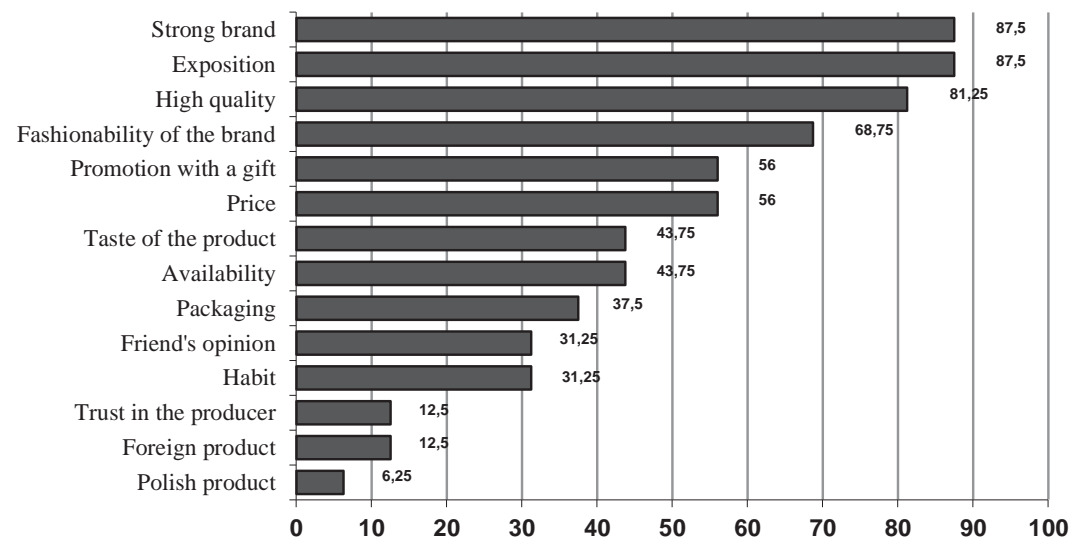

Figure 3. Key decision elements in the process of spirits purchase

Source: K. Liczmańska, own research, personal interview, 2007, N=1501 individual respondents

Respondents first mention a strong brand and the exposition of a product, which in fact aids awareness and recollection of a brand [23, 214] $-87.5 \%$ for each option. In the analyzed sector it is, therefore the ability to build a strong brand and maintain it that plays a key role. Looking At responses supplied by consumers it is impossible not to notice how great the influence of vodka producers and their marketing activities is on the preferences and purchase decisions of consumers. 
The third most common indication with $81.25 \%$ is the quality of the product. The question is how well consumers can tell the difference in quality of the products. Have they tested and compared different brands, or do they subconsciously trust a brand which guaranteed the quality $[18,45]$. In the fourth place $(68.75 \%$ indications) we have the factor of how fashionable a brand is. This factor is the effect of a high brand awareness and acceptability combined with a positive image. Consumers also find promotion and an adequate price important (56\% indications each). The taste and availability of the product both got $43.75 \%$ of indications.

It is worth noticing that when building a strong brand one should consider the various senses involved in the evaluation of a product's quality, that is to say in the evaluation of its uniqueness. Taste remains an important element $[17,68]$. While the product's country of origin, producer, as well as trust in the producer seem to be the least important factors. The consumer preferably chooses a brand without paying any attention to its country of origin or producer. This gives ground to abandon the hypothesis of a conscious ethnocentrism among Polish vodka consumers (the subject requires separate research). Figure 4 shows the strong brand in a set of purchase decisions determinants in sectors where media advertising is banned.

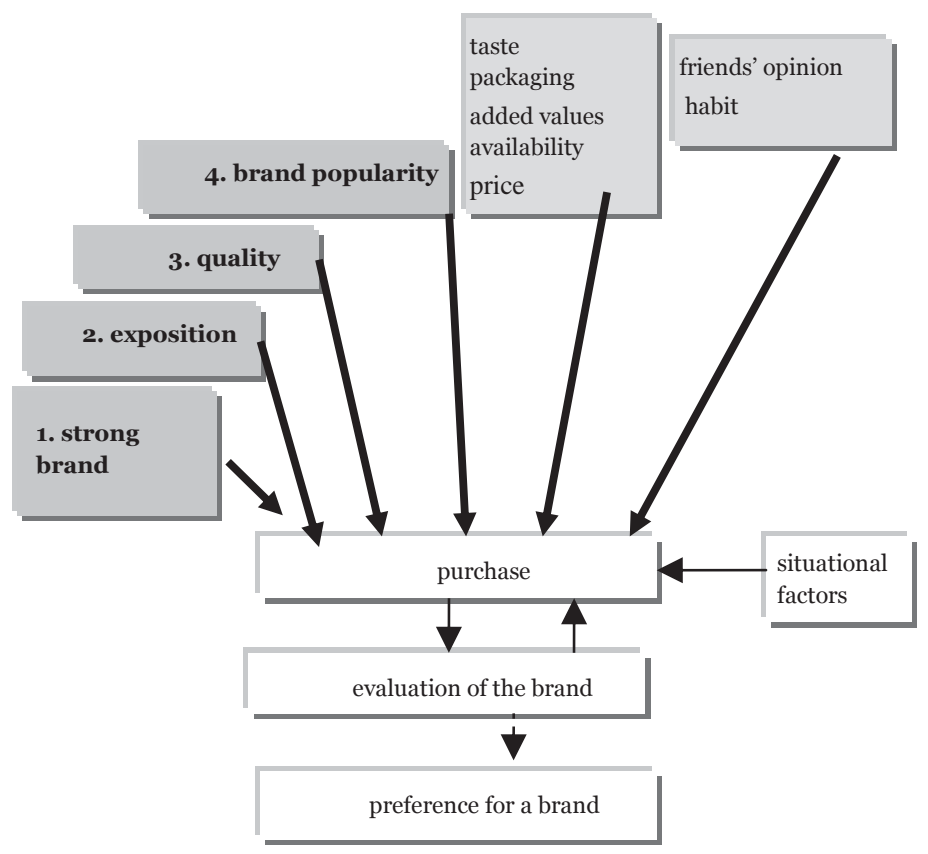

Figure 4. A strong brand in the set of purchase decision determinants in sectors, where media advertising is banned 
The importance of a strong brand, shown here in first position is clearly visible. It can therefore be assumed that, in the case of vodka a strong brand is what consumers actually buy. The producers' opinion on the decisive factors in vodka brand selection are shown in Table 1.

Table 1

Evaluation of the importance of factors in the vodka purchase decision process

\begin{tabular}{|l|c|}
\hline & Totals \\
\hline Brand popularity & 79 \\
\hline Exposition & 74 \\
\hline Availability & 71 \\
\hline Friends' opinion & 70 \\
\hline Taste of the product & 66 \\
\hline Attractiveness of the packaging & 64 \\
\hline Price & 63 \\
\hline Added values & 62 \\
\hline Habit & 61 \\
\hline Quality & 57 \\
\hline Foreign product & 51 \\
\hline Polish product & 45 \\
\hline Trust in the producer & 42 \\
\hline
\end{tabular}

Explanation: a scale of points $1-5$ where 5 is the highest grade

Source: K. Liczmańska, own research, direct and Internet questionnaire, 2007, N=16 companies accounting for $95,95 \%$ of the market share of alcoholic beverages in Poland

The main difference between producers and consumers in the perception of the importance of particular factors in the purchase process concerns the trendiness of a brand. Producers ranked it as the most important factor, while consumers gave it fourth place. While analyzing trends producers notice what consumers would prefer not to mention - that they are in fact influenced by fashion. Consumers would like to stress the sovereignty and rationality of their choices and are more likely to admit that they have selected the best brand, not the trendiest one. The effect is that the chosen brand gains popularity grows in strength and eventually becomes trendy.

The other significant difference is in the evaluation of the significance of brand availability (fourth place according to producers and eighth place according to consumers). Availability combined with the highly valued by both groups of re- 
spondents exposition maintains brand awareness in the absence of advertisements in mass media. Producers believe the product's quality is of lesser importance (eleventh place in the producers' ranking and third according to consumers). This can indicate that in the producers' opinion consumers buy the brand and not the product - quality is a secondary purchase stimulus which affects brand image and builds its strength, which in turn determines purchase decisions.

A conclusion may therefore be drawn that there are certain interdependencies between factors in the set of purchase decision determinants. The most prominent of these interdependencies seem to exist between the strength of the brand and the rest of the determinants. The conceptual model has been illustrated in the Figure 5.

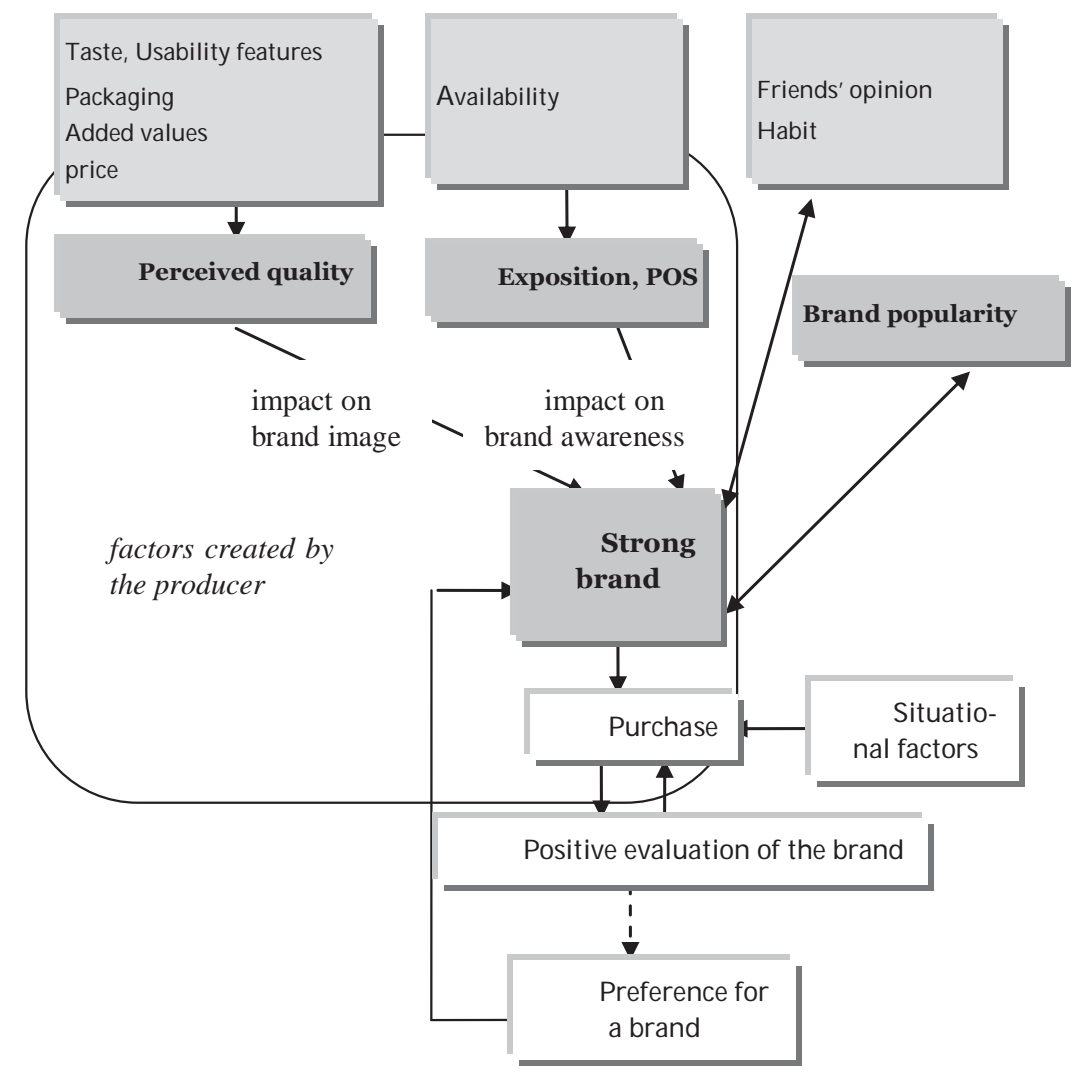

Figure 5. The conceptual model of determinants of the strong brands and of influence of a strong brand on purchase decisions in the sector where public advertising is prohibited 
Brand awareness and brand image are the key construction elements of brand strength. A strong brand specializes in supplying the consumer with exceptional benefits. A strong brand is well-known by consumers and plays an important role in meeting their needs, is respected and has prestige.

In sectors where there is a ban on alcohol advertising in mass media producers exploit other stimuli within the set of purchase decision determinants to build strong brands. Companies retained control over stimuli which are important for buyers such as product display in points of sale and availability, which is a sine qua non condition for display management. Quality is also important although it is a rather subjective form of evaluation based on factors such as taste or other product traits, packaging, price and added value.

Investing in tools which affect consumers' evaluation of product quality and at the same time ensure adequate product exposure at point of sale means that a company is able to build a strong brand without advertising in mass media.

Fashion, understood as a commonly accepted or even desired style in a given social group is a temporary phenomenon. It is, on the one hand the effect of brand strength, and on the other it increases brand strength. A company may either build on that effect, and create a stable market position for the brand, or it may loose the opportunity and let the interest in the brand pass with the fashion - it largely depends on marketing management skills. When a brand is in fashion the company should build consumers' appreciation. Then, regardless of the trends the brand's strength will be supported by purchase habits (brand market share) and by recommendations to friends (brand awareness and brand image).

\section{The benefits producers get from strong brands}

In order to beat its competition a company should decide which of its assets, processes and functions is most suitable to achieve this. Attributes such as a low price, innovative technology or even a good distribution chain are all easily duplicated by competitors so the more desired attributes are those which cannot be easily copied and provide the company with a lasting competitive advantage.

The assets theory states that assets and abilities that are rare, lasting, imperfectly mobile and difficult to imitate enable the company to gain a sustainable competitive advantage [2, 97]. Companies usually build their strategies basing simultaneously on various attributes, one of them is almost always a brand because branded products are chosen more frequently than unbranded ones [20, 220].

Vodka consumers and producers confirm that strong brands do exist in the vodka sector, although advertising in mass media is completely banned. All 
the respondents (consumers and producers) confirmed the existence of strong brands, and $50 \%$ of the respondents are of the opinion that the ban on vodka advertising in mass media did not eliminate the development of strong alcohol brands. The producers were also asked about the benefits that strong brands bring (Figure 6).

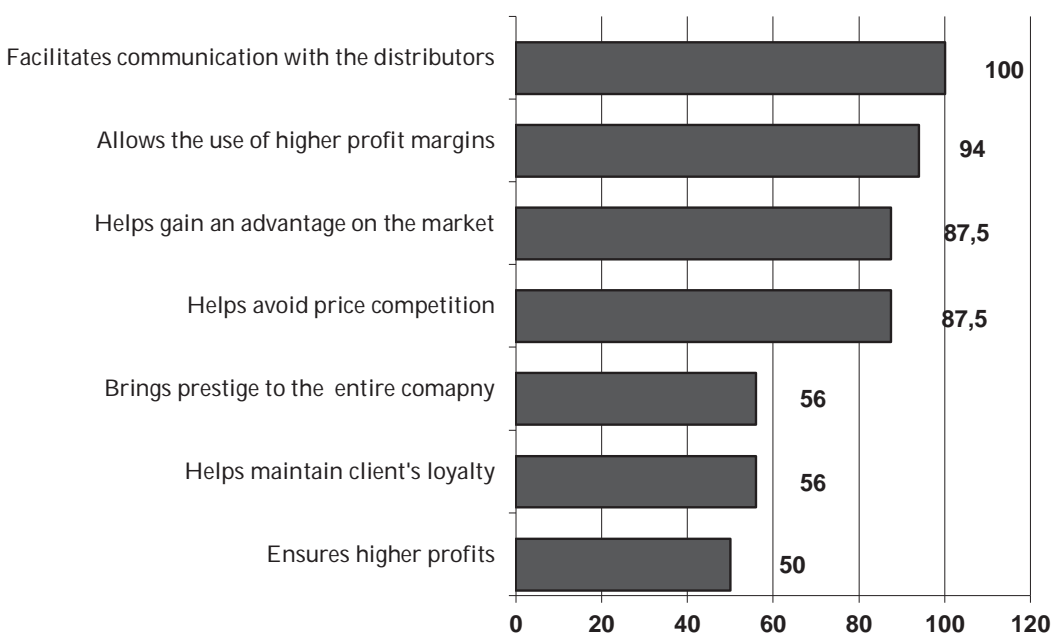

Figure 6. Benefits of strong brands for producers

Source: K. Liczmańska, own research, direct and Internet questionnaire, 2007, N=16 companies accounting for $95,95 \%$ of the market share of alcoholic beverages in Poland

According to producers brands help to gain substantial benefits directly affecting company prestige and finances. It is not surprising then how much effort producers make to build and nurture strong brands. Almost all the companies examined (from $87.5 \%$ to $100 \%$ ) mention benefits such as: facilitated communication with distributors, being able to increase margins, ensuring a market advantage, being able not to use prices as competition tools. Half of the respondents point to yet other arguments in favour of strong brands: they bring prestige for the entire company, maintain customer loyalty and increase profits.

Other facts which show the influence of particular factors on the success of a company in the spirits sector were collected in course of analyzing the results provided by producers and are shown below (Table 2). 
Table 2

Evaluation of the influence of particular factors o company success in the spiritus sector

\begin{tabular}{|l|c|}
\hline & Totals \\
\hline Strong brands in a portfolio & 78 \\
\hline Promotional activity on a large scale & 74 \\
\hline Adequate product price & 63 \\
\hline Widespread distribution & 60 \\
\hline Strong organizational culture & 57 \\
\hline Well developer sales department & 56 \\
\hline Competitive conditions for distributors & 55 \\
\hline Qualified staff & 55 \\
\hline Company's own distribution chain & 53 \\
\hline Large investments in research and development & 50 \\
\hline
\end{tabular}

Explanation: scale of points 0-5.

Source: K. Liczmańska, own research, direct and Internet questionnaire, 2007, N=16 companies accounting for $95.5 \%$ of the spirits market in Poland

According to representatives of companies in the spirits sector the most important factor contributing to company success is a strong brand in the portfolio. As many as 14 out of 16 companies pointed to a strong brand as the key factor, while only two companies did not give it the highest rating. Taking into account earlier responses from companies in this sector, the end consumers questioned and results from the table above there is no doubt that strong vodka brands exist and are of paramount importance to their owner's success. A unified opinion of both large and small companies in the sector attests to the dominant role of brands in the creation of company success.

The second most highly valued by vodka producers factor is large scale promotional activity. Vodka producers find ways of communicating with consumers and allocate enormous sums of money for point of sale promotion, almost the only form of communication allowed by the Act on Alcoholism Prevention. This means there are ways of distinguishing the brand from other brands and influencing contact of potential buyers with the brand name, supporting brand awareness and eventually building strong brands.

The respondents mention an adequate price in the third place. Yet an analysis of brands declared by consumers as the most frequently purchased and their market share show that expensive products are at the top of the rankings. 
An adequate price however may not mean a low price, as it is the consumer's acceptance of a price for the quality of the product and the value added by the brand that is important for the company's success.

A wide distribution is the fourth important factor indicated by company representatives. As has been noted in the consumer study product availability plays a relatively important role in the purchase of vodka. A consumer who does not find his favourite vodka brand on the shelf simply buys a different brand, often tempted by an attractive promotion. In this particular sector, where communication with the consumer may be established virtually only at point of sale product availability and ensuring its presence in distribution channels is of primary importance.

Other factors such as a strong organizational culture, a well-developed sales department, competitive conditions for distributors, qualified staff, a distribution chain owned by the company and investment in research and development were rated as less important, which does not mean they do not play any role in building company success. The well- developed sales department is of particular interest. It has been noticed that excellent product display and activities at point of sale are key elements in the consumer's selection process of vodka brands. Consequently, a well-developed sales department owned by the company where sales representatives have direct access to points of sale seems to affect company success in this sector. However, market observation has shown that companies with smaller sales departments employ the wholesalers' representatives. They work as merchandisers as well as brand ambassadors playing an important role in the communication process between producers and retailers.

A brand considered in the context of its name, value or loyalty became decades ago a powerful force in business which can be shaped and managed [19, 78]. The significance of the brand as a tool of communication between the company and the buyers increases proportionally to the need for differentiating the product from competitors' products and the need for its identification [13, 98].

A strong brand enjoying a group of loyal consumers almost 'sells itself'. Research has shown that consumers know which brand they want to buy and do precisely that once in the shop. Their favourite brands are often the leaders in both popularity rankings and market share. Promotions noticed by consumers belonged to brands which were most frequently purchased when the decision was made just before purchase at the store. Consumers notice strong brands and have their own preferences. When asked if they were aware of marketing activity on the part of vodka producers, $89 \%$ said yes.

Two models of consumer behaviour may be noticed in which the brand and promotion make consumers aware of its existence and its benefits, at the same time playing a major role in the decision. In the first model the consumer goes to a retailer with the intention of buying a particular (preferred) brand of 
alcohol. It is important for the brand to be available. Otherwise promotional activities of other brands at the point of sale will shift the consumer's attention to another known brand or even initiate interest in a completely new one. The second model assumes that the consumer goes to the retailer with the intention of buying vodka, but without preference for a particular brand or considering one of many brands [22,30]. Hence the final decision depends on availability and communication activity provided for the brand by the producer. In both cases the brand often bought and consumed in circumstances marking a special event such as a birthday party or other celebration may become a brand the consumer will return to in the future. It could be described as pull effect. Strong brands facilitate producers' activities in distribution channels.

A consumer is ready to pay more for his favourite brand than for other brands which ensures a higher profit for the producer. It also allows distribution channels to set higher margins. Such a situation is very beneficial for the brand producer because both the wholesalers and retailers are willing to sell products at a higher margin to earn more.

An established brand transfers its strength and prestige to the entire company. This fact is exploited by companies in the spirits sector. The Bols Company has taken its name from its main brand Bols Vodka. The Sobieski Vodka is another example, its owner being Sobieski Company. Other examples include vodkas like Wybrowa, Luksusowa. It is easier to launch products under a known brand name and this occurs in the case of the most popular vodka brands. The brands are expanded to include new flavours, products in various price ranges or even different beverages altogether, such as RTD drinks, liqueurs, and other kinds of alcoholic beverages.

\section{Conclusions}

In the highly competitive market of strong alcoholic beverages with the ban on advertising in mass media which would greatly help in influencing purchase decisions, a distinguishable brand becomes one of the key elements of a competitive advantage and a guarantee of success.

Analyses of the research conducted have shown that a strong brand is vodka's greatest asset. Consumers notice them and buy products of established brands. Producers manage to carry out promotional activities well in spite of the ban on advertising in mass media. They are effective enough to be noticed by consumers who consciously choose vodka brands. Vodka brands which have been successfully positioned in the highest places in consumers' awareness are at the same time the best selling brands. 
The material collected supported the thesis that consumers point to a strong brand as the key factor in choosing high end vodkas. All producer representatives stress the need to build strong brands and declare having such brands in their offer. This confirms the thesis put forward by the authors of this paper. The research clearly shows that alcohol producers believe building and sustaining strong brands to be the main source of competitive advantage. Producers know the market well as consumers point to all factors associated with the brand as key elements influencing their choices of vodka brands. A strong, well-known brand is very important. Undoubtedly a strong brand is the most important competitive asset a company may have in the vodka sector.

More and more companies believe that brands may be treated as company assets whose value may be reflected in the balance sheet, at the same time increasing company value. The growing importance of the brand is emphasized by L.B. Upshaw: 'brands have become the core of contemporary, consumer oriented capitalistic economy where the mutual effect of brands enlivens trade exchange' (Upshaw, 1995, p. 11). The vodka sector described above is not an exception and, in spite of the tight restrictions concerning alcohol advertisements in mass media, strong vodka brands exist and producers take good care of them. This is not in the least surprising as strong brands are key success factors.

\section{References}

[1] Aaker D.A., Building Strong Brands, "The Free Press", New York 1999.

[2] Amit R., Schoemaker P., Strategic assets and organizational rent, "Strategic Management Journal", Vol. 14/1993, pp. 33-46.

[3] Arslan F.M., Altuna O.K., The effect of brand extensions on product brand image, "Journal of Product \& Brand Management" 2010, Vol 19, Issue 3, pp. 170-180.

[4] Chaudhuri A., Holbrook M.B., The chain of effects from brand trust and brand affect to brand performance: the role of brand loyalty, "Journal of Marketing", Vol. 65, No. 2, pp. 81-93.

[5] de Chernatony L., Marka. Wizja i tworzenie marki, Gdańskie Wydawnictwo Psychologiczne, Gdańsk 2003.

[6] Dąbrowska K., Marketing alkobolu w Polsce, „Remedium” 2006, Vol. 10, pp. 4-5.

[7] Farquhar P.H., Managing brand equity, "Marketing Research" 1989, Vol. 1, September, pp. 24-33.

[8] Grzegorczyk A., Reklama, Polskie Wydawnictwo Ekonomiczne, Warszawa 2010.

[9] Kall J., Silna marka, Polskie Wydawnictwo Ekonomiczne, Warszawa 2001. 
[10] Keller K.L., Strategic Brand Management: Building, Measuring and Managing Brand Equity, Prentice-Hall, Upper Saddle River, New York 2008.

[11] Kimpakorn N., Tocquer G., Service Brand equity and employee brand commitment, "Journal of Services Marketing" 2010, Volume 24, Issue 5, pp. 378-388.

[12] Kotler Ph., Marketing. Analiza, planowanie, wdrażanie i kontrola, Wydawnictwo Rebis, Warszawa 2005.

[13] Kotler Ph., Keller K.L., Marketing Management 12e, Pearson Prentice Hall, Upper Saddle River 2006.

[14] Kozłowska A., Reklama. Techniki perswazyjne, Oficyna Wydawnicza Szkoła Główna Handlowa w Warszawie, Warszawa 2011.

[15] Liczmańska K., Efekt kraju pocbodzenia produktu a decyzje nabywcze konsumentów sektora alkoboli wysokoprocentowych, Roczniki Ekonomiczne Kujawsko-Pomorskiej Szkoły Wyższej w Bydgoszczy 2010, No. 3, pp. 177-187.

[16] Liczmańska K., Silna marka jako źródto przewagi konkurencyjnej $w$ momencie zakupu, Roczniki Ekonomiczne Kujawsko-Pomorskiej Szkoły Wyższej w Bydgoszczy 2008, No. 1, pp. 87-99.

[17] Lindstrom M., Brand Sense: Build Powerful Brands Through Touch, Taste, Smell, Sight and Sound, Free Press, New York 2005.

[18] Maison D., Utajone postawy konsumenckie, Gdańskie Wydawnictwo Psychologiczne, Gdańsk 2004.

[19] Marconi J., Marketing marki. W jaki sposób tworzyć, zarządzać i rozszerzać wartość marki, Liber, Warszawa 2002.

[20] Taylor S.A., Celuch K., Goodwin S., The importance of brand equity to customer loyalty, "Journal of Product and Brand Management" 2004, Vol. 13, Issue 4, pp. 217-227.

[21] Upshaw L.B., Building Brand Identity. A strategy for Success in a Hostile Marketplace, John Wiley \& Sons, New York 1995.

[22] Wiśniewska A., Czynniki decydujące o wrażliwości konsumentów na markę, in: (ed.) A. Grzegorczyk, Instrumenty ksztaltowania wizerunku marki, Wyższa Szkoła Promocji w Warszawie, Warszawa 2005, pp. 13-31.

[23] Zimbardo Ph.G., Leippe M.R., Psychologia zmiany postaw i wplywu spolecznego (The Psychology of Attitude Change and Social Influence), Wydawnictwo Zysk i S-ka, Poznań 2004. 